\title{
17. SEDIMENTOLOGICAL AND GEOCHEMICAL CHARACTERISTICS OF THE UPPER CRETACEOUS AND LOWER TERTIARY SEDIMENTS AT SITE 661 (EASTERN EQUATORIAL ATLANTIC) AND THEIR PALEOENVIRONMENTAL SIGNIFICANCE ${ }^{1}$
}

\author{
Ruediger Stein ${ }^{2}$ and Jean-Claude Faugères ${ }^{3}$
}

\begin{abstract}
Based on sedimentological and geochemical data, the Upper Cretaceous and Tertiary sequence at Ocean Drilling Program Site 661 was subdivided into four intervals:

Interval I (Campanian age) is characterized by sediments deposited below the calcite compensation depth (CCD) inside a high-productivity area and well-oxygenated bottom waters, indicated by the absence of carbonate, the major occurrence of zeolites and opal-CT, and intense bioturbation. Very fine-grained siliciclastic sediments and the lack of any erosional features suggest a low-energy environment. The terrigenous fraction was probably supplied by winds from the nontropical areas in South Africa.

Interval II (Maestrichtian age) is characterized by high-amplitude variations in the carbonate content indicative of a deposition above the CCD, superimposed by (climate-controlled) short-term fluctuations of the CCD. The absence of both zeolites and opal-CT imply a position of Site 661 outside high-productivity areas. The first occurrence of higher amounts of kaolinite (especially during the middle Maestrichtian) suggests the onset of a terrigenous sediment supply from tropical areas.

Interval III (between uppermost Cretaceous to early Tertiary) is characterized by the absence of carbonate and zeolites, interpreted as deposition below the CCD and outside an oceanic high-productivity belt. The kaoliniteover-illite dominance suggests a terrigenous sediment supply from tropical areas.

Interval IV (between early Tertiary and Miocene age) is characterized by the occurrence of black manganeserich layers, major nodules/pebbles, and erosional surfaces, indicating phases of extremely reduced sediment accumulation and bottom-current activities. In the lower part of this interval (?Eocene age), higher amounts of zeolites occur, which suggest a higher oceanic productivity caused by equatorial upwelling. The source area of the terrigenous sediment fraction at Site 661 was the tropical region of northwest Africa, as suggested by the kaolinite-over-illite dominance.
\end{abstract}

\section{INTRODUCTION}

During Leg 108, five sites were drilled on the northwest African continental margin. One of these sites, Site 661, reached sediments older than Cenozoic age. Site 661 is located on the Sierra Leone Rise, on a plateau east of the Kane Gap at a water depth of $4072 \mathrm{~m}$ (Fig. 1). The Kane Gap separates the rise into two parts: the Guinea continental margin in the east and the outer Sierra Leone Rise in the west (Fig. 1). The gap is a major passage for deep-water exchange between the southern Sierra Leone Abyssal Plain and the northern Gambia Abyssal Plain (Fig. 1) at least since Miocene times, possibly since the end of Eocene times (Fig. 1; Jacobi and Hayes, 1982; Sarnthein et al., 1982; Mienert, 1986). Thus, in the Kane Gap area, Tertiary sedimentary processes are strongly influenced by bottom-current activities, which could have caused erosion and/or nondeposition.

Seismic $(3.5 \mathrm{KHz})$ records from this area (Mienert, 1986), as well as borehole data from Sites 659, 660, and 661 (Ruddiman, Sarnthein, et al., 1988), strongly support bottom-current processes. Site 661 , located closest to the Kane Gap, shows a reduced Tertiary sequence of about $85 \mathrm{~m}$, including major hiatuses (Fig. 1; Ruddiman, Sarnthein, et al., 1988). Below the

\footnotetext{
${ }^{1}$ Ruddiman, W., Sarnthein, M., et al., 1989. Proc. ODP, Sci. Results, 108: College Station, TX (Ocean Drilling Program).

2 Institut für Geowissenschaften und Lithosphärenforschung (IGL), Universität Giessen, Senckenbergstrasse 3, 6300 Giessen, Federal Republic of Germany.

${ }^{3}$ Laboratoire de Géologie-Océanographie, Université de Bordeaux I, Avenue des Facultés, Talence 33405 Cedex, France.
}

Tertiary sequence, about $180 \mathrm{~m}$ of Campanian to Maestrichtian sediments have been cored at Site 661 (Fig. 1).

The entire section recovered from Hole 661A comprises three lithologic units (Ruddiman, Sarnthein, et al., 1988):

1. Unit 1 contains uppermost Miocene to Holocene cyclic pelagic or hemipelagic sediments with a sedimentation rate of $15 \mathrm{~m} / \mathrm{m} . \mathrm{y}$.

2. Unit 2 consists of lower upper Miocene brownish to reddish clay and is nonfossiliferous, except for the uppermost part where rare nannofossil oozes are interbedded. The sedimentation rate is about $4 \mathrm{~m} / \mathrm{m} . \mathrm{y}$. for the uppermost part and less than $0.5 \mathrm{~m} / \mathrm{m}$.y. for the underlying deposits.

3. Unit 3 is composed of Upper Cretaceous to Tertiary bluish green, partly zeolite-rich clay and claystone with interbedded Maestrichtian nannofossil oozes in the middle part. Two horizons with striking color changes, metallic nodules, and erosional features underlay the top of Unit III. The sedimentation rate, more difficult to estimate, is about 3 $\mathrm{m} / \mathrm{m} . \mathrm{y}$.

In this paper, we have concentrated on the changes in depositional environment at Site 661 during Late Cretaceous and early Tertiary times.

\section{METHODS}

Carbonate content was determined by $\mathrm{CHN}$-analyzer and carbonate bomb. Bulk mineralogy data was obtained from X-ray diffraction (XRD) measurements performed on powder slides using a Philips ADP 3520 instrument or a Siemens D 500 instrument. Data shown in Figure 2 and Table 2 are based on quartz $(4.26 \AA)$, illite/mica $(10 \AA)$, kaolinite (+ chlorite) $(7.1 \AA)$, zeolites (8.84-9.91 $\AA$, and opal-CT 


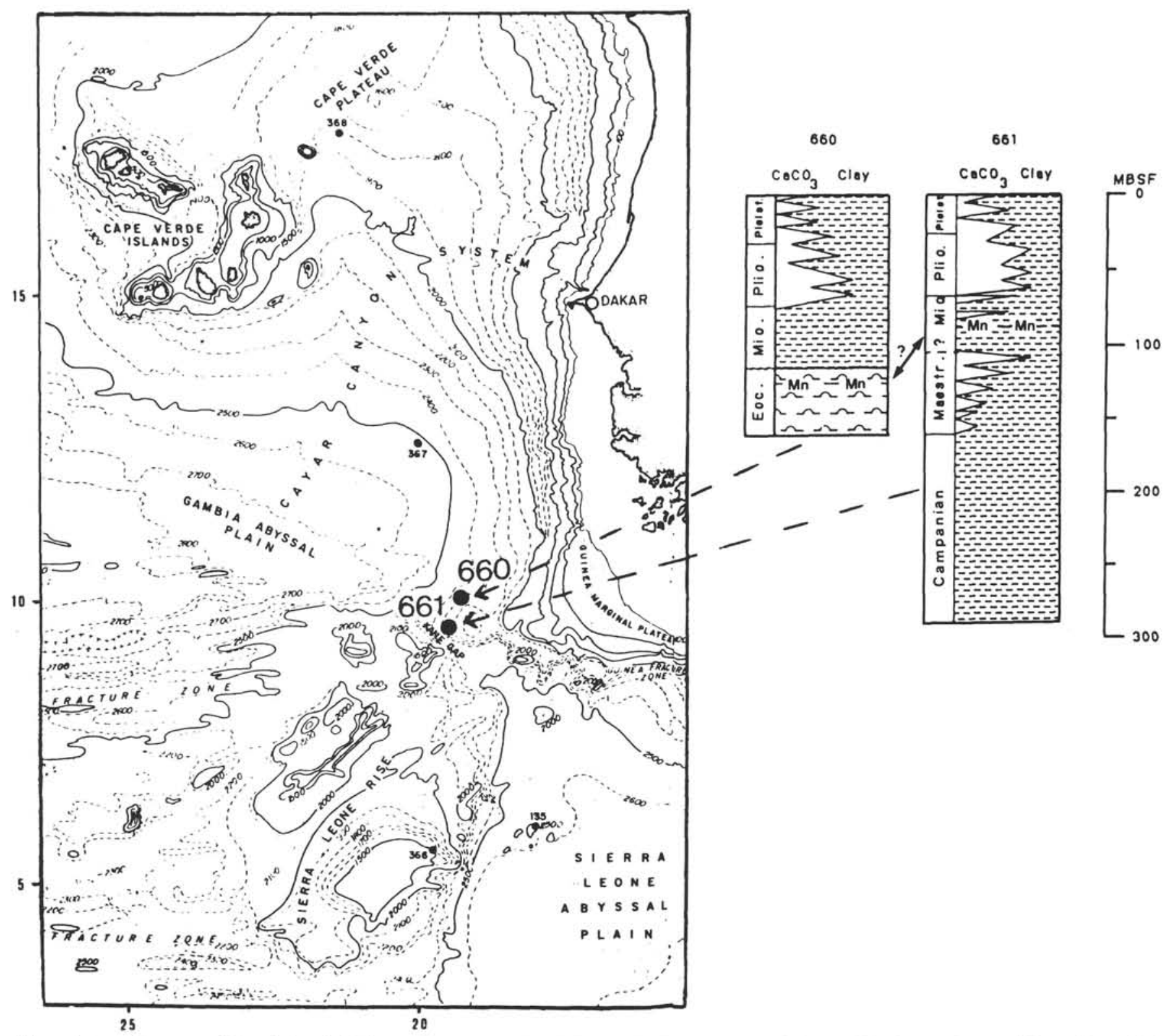

Figure 1. Location map of Sites 660 and 661 (according to Jacobi and Hayes, 1982); contours in fathoms. Lithology columns of Sites 660 and 661 from Ruddiman, Sarnthein, et al., 1988. Mn = manganese-rich black layers, “ " = radiolarian ooze. Stratigraphy from Ruddiman, Sarnthein, et al. (1988) and J. Thurow (pers. comm., 1988).

(4.04-4.1 $\AA$ ) intensity values and are relative numbers expressed as quartz/halite, zeolite/halite, opal-CT/halite, and kaolinite/illite ratios. Halite $(1.99 \AA)$, as a pore-water precipitate present in all dried, unwashed samples, is used as an internal standard. A correction for porosity is not included because the porosity data available for this interval only show small variations between $55 \%$ and $70 \%$ (Ruddiman, Sarnthein, et al., 1988).

Detailed grain-size analyses on silt and clay fractions were performed using a SediGraph instrument (for methodology, see Stein, 1985a) and a Malvern 3600 Ec instrument (Robbe and Bertrand, 1987; Weber et al., in press).

The descriptions of sedimentary structures and nodules are based on the visual core descriptions (Ruddiman, Sarnthein et al., 1988) and the evaluation of core photographs.

\section{RESULTS}

From sedimentological and geochemical results, we can separate lithologic Unit 3 into four intervals. Interval I corre- sponds to Subunit 3b, and Intervals II, III, and IV correspond to Subunit 3a (Fig. 2; Ruddiman, Sarnthein, et al., 1988).

\section{Interval I}

\section{Sections 108-661A-32X (296.1 mbsf) to 108-661A-19X-1 (163.1 mbsf)}

Interval I is characterized by greenish gray homogeneous clay and claystone. According to detailed grain-size analyses by SediGraph and Malvern instruments, the sediments mainly consist of clay and fine silt; median diameters remain very low (Fig. 3 , Table 1 ). The sandy fraction is absent or only occurs in very minor amounts and is composed of indurated aggregates and pyritic grains. The lower part (i.e., Cores 108-661A-32X to -23X) is highly indurated (claystone). Pyrite nodules are frequently scattered throughout the section. The sediments are moderately 


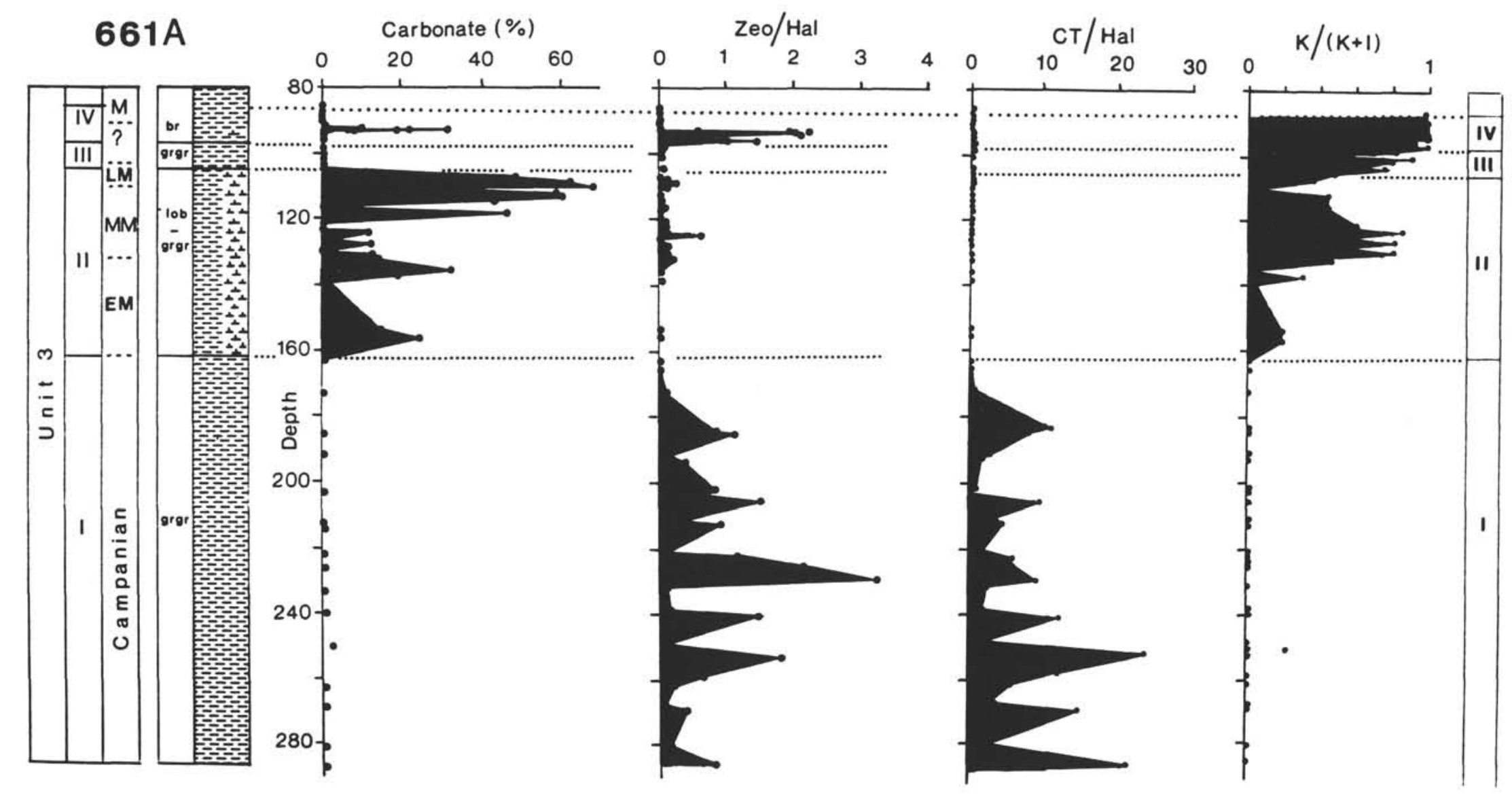

Figure 2. Summary diagram of carbonate, zeolite, opal-CT, and kaolinite contents of lithologic Unit 3, Intervals I to IV. Stratigraphy and lithology from Ruddiman, Sarnthein, et al., 1988. The stratigraphic age of Interval I (Campanian) is based on radiolarians (J. Thurow, pers. comm., 1988). Zeolite and opal-CT data are expressed as XRD intensity ratios of zeolite/halite $(\mathrm{Zeo} / \mathrm{Hal})$ and opal-CT/halite $(\mathrm{CT} / \mathrm{Hal})$, respectively. The kaolinite values are expressed as kaolinite/(kaolinite + illite); that is, $\mathrm{K} /(\mathrm{K}+\mathrm{I})$. $\mathrm{M}=$ Miocene, $\mathrm{LM}=$ late Maestrichtian, $\mathrm{MM}=$ middle Maestrichtian, $\mathrm{EM}=$ early Maestrichtian, $\mathrm{br}=$ brownish, grgr $=$ greenish gray, and lob $=$ light olive brown. 


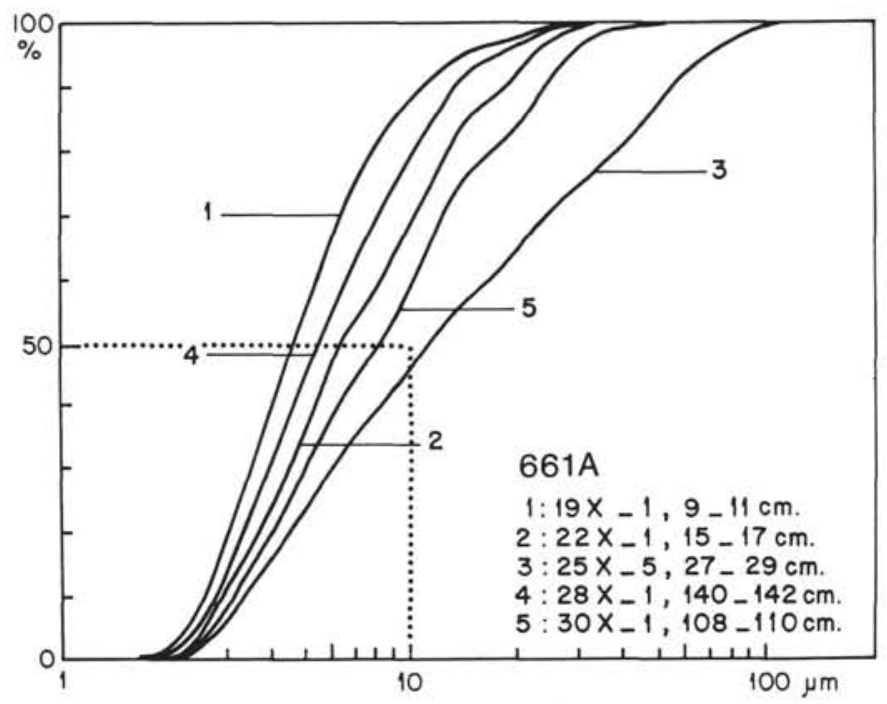

Figure 3. Results of grain-size analyses of sediment samples from Interval I, using laser diffraction technique (for methodology, see Robbe and Bertrand, 1987; Weber et al., in press). Compare with Table 1.

Table 1. Results of grain-size analyses using the Malvern laser diffraction technique.

\begin{tabular}{|c|c|c|c|c|}
\hline $\begin{array}{l}\text { Core, section, } \\
\text { interval }(\mathrm{cm})\end{array}$ & $\begin{array}{c}>63 \mu \mathrm{m} \\
(\%)\end{array}$ & $\begin{array}{l}\text { Clay } \\
(\%)\end{array}$ & $\begin{array}{c}\text { Median } \\
\text { diameter } \\
(\mu \mathrm{m})\end{array}$ & $\begin{array}{l}\text { Lithologic } \\
\text { units }\end{array}$ \\
\hline \multicolumn{5}{|l|}{ 108-661A- } \\
\hline $11 \mathrm{H}-4,89-90$ & 1 & 42 & 7.7 & \\
\hline $11 \mathrm{H}-4,107-108$ & 0.2 & 32 & 9.6 & $\uparrow \geq$ \\
\hline $11 \mathrm{H}-4,112-113$ & - & 25 & 12.1 & $\mathrm{H} 2 \overline{\mathrm{\pi}}$ \\
\hline $11 \mathrm{H}-4,118-119$ & - & 23 & 10.7 & $\downarrow$ 己 ल \\
\hline $11 \mathrm{H}-5,41-42$ & 1 & 44 & 6.8 & $\uparrow \cong$ \\
\hline $11 \mathrm{H}-5,47-48$ & 5.2 & 45 & 7.0 & $\mathrm{H} 1=5$ \\
\hline $11 \mathrm{H}-5,54-55$ & 1.5 & 26 & 11.7 & $\downarrow \mid \stackrel{\Xi}{\sharp}$ \\
\hline $11 \mathrm{H}-5,105-107$ & 0.7 & 30 & 9.4 & \\
\hline $11 \mathrm{H}-6,88-90$ & - & 55 & 5.5 & $\uparrow$ \\
\hline $12 \mathrm{H}-4,18-20$ & - & 63 & 4.8 & $\equiv$ \\
\hline $13 \mathrm{H}-3,148-150$ & - & 58 & 5.3 & I \\
\hline $18 X-1,7-9$ & - & 56 & 5.4 & $\stackrel{\uparrow}{=}$ \\
\hline $19 X-1,9-11$ & - & 68 & 4.6 & $I$ \\
\hline $20 \mathrm{X}-1,24-26$ & - & 43 & 7.1 & \\
\hline $22 \times-1,15-17$ & - & 48 & 6.4 & \\
\hline $23 X-2,50-52$ & - & 56 & 5.6 & \\
\hline $24 \mathrm{X}-2,134-136$ & 5.5 & 28 & 13.4 & $=$ ले \\
\hline $25 \times-5,27-29$ & 8.0 & 31 & 11.1 & 要 \\
\hline $27 \mathrm{X}-1,68-70$ & - & 35 & 9.8 & \\
\hline $28 \mathrm{X}-1,140-142$ & - & 45 & 6.7 & 巨苛 \\
\hline $29 \mathrm{X}-4,9-11$ & 3.3 & 33 & 10.6 & \\
\hline $30 \mathrm{X}-1,108-110$ & - & 58 & 5.3 & \\
\hline $31 X-4,10-12$ & - & 56 & 5.5 & \\
\hline
\end{tabular}

Note: Lithologic subunits, Intervals I through IV, and horizons HI and $\mathrm{H} 2$ are indicated on the right side of the table. For an explanation of the Malvern technique, see Robbe and Bertrand (1987) and Weber et al. (in press).

to highly bioturbated with a higher rate of bioturbation observed in darker layers (Fig. 4, 104-105 cm).

Different kinds of burrows occur: Zoophycos, Chondrites, and Planolites (Fig. 4). The burrows are elongated parallel to the bedding due to compaction. The upper part of Interval I (Cores 108-661A-22X to -19X) is less lithified and consists of clay (Cores 108-661A-20X and -19X) with a transitional zone of alternating clay and claystone in Cores 108-661A-22X and $-21 \mathrm{X}$. Parallel to the decrease in lithification, the occurrence of pyrite nodules also decreases (cf. the lithologic core descrip-

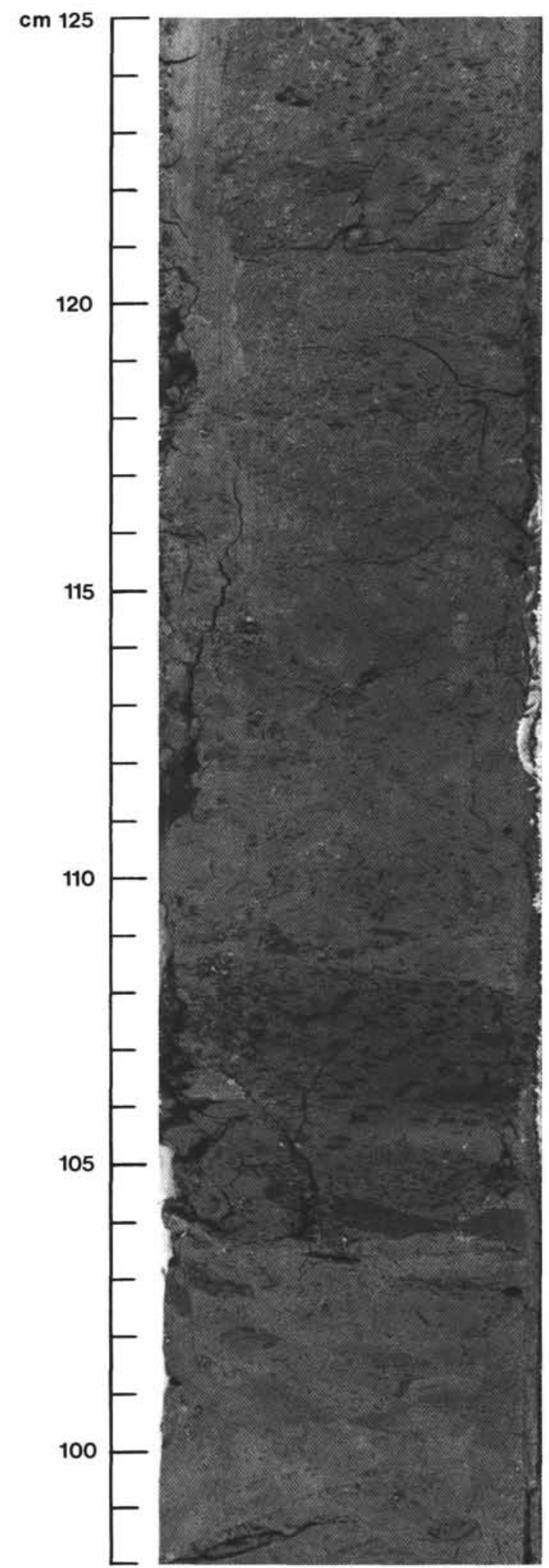

Figure 4. Photograph of Section 108-661A-23X-1, 98-125 cm, showing intense bioturbation (i.e., Zoophycos, Planolites, and Chondrites). Burrows are elongated due to compaction. Scale on the right in centimeters. 
Table 2. Carbonate contents, relative X-ray diffraction intensities of quartz $(4.26 \AA)$, illite/mica $(10 \AA)$, kaolinite $(+$ chlorite) $(7.1 \AA)$,

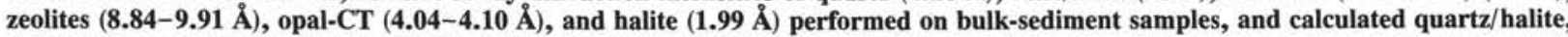
zeolite/halite, opal-CT/halite, and kaolinite/(kaolinite + illite) ratios.

\begin{tabular}{|c|c|c|c|c|c|c|c|c|c|c|c|c|}
\hline \multirow{2}{*}{$\begin{array}{l}\text { Core, section, } \\
\text { interval }(\mathrm{cm})\end{array}$} & \multirow{2}{*}{$\begin{array}{l}\text { Depth } \\
\text { (mbsf) }\end{array}$} & \multirow{2}{*}{$\begin{array}{c}\mathrm{CaCO}_{3} \\
(\%)\end{array}$} & \multicolumn{6}{|c|}{ Relative X-ray diffraction intensities } & \multirow[b]{2}{*}{ Qua/Hal } & & & $\mathbf{K}$ \\
\hline & & & Quartz & Illite & Kaolinite & Zeolites & Halite & Opal-CT & & $\mathrm{Zeo} / \mathrm{Hal}$ & $\mathrm{CT} / \mathrm{Hal}$ & $\mathrm{K}+\mathrm{I}$ \\
\hline $108-661 \mathrm{~A}-$ & & & & & & & & & & & & \\
\hline $11 \mathrm{H}-1,105$ & 88.15 & 0.2 & 331 & 10 & 234 & 0 & 128 & 0 & 2.6 & 0 & 0 & 1.0 \\
\hline $11 \mathrm{H}-2,105$ & 89.65 & 0.2 & 240 & 32 & 180 & 0 & 110 & 0 & 2.2 & 0 & 0 & 0.8 \\
\hline $11 \mathrm{H}-3,105$ & 91.15 & 0.2 & 279 & 10 & 328 & 0 & 154 & 0 & 1.8 & 0 & 0 & 1.0 \\
\hline $11 \mathrm{H}-4,79$ & 92.39 & 10.0 & 76 & 0 & 34 & 0 & 92 & 0 & 0.8 & 0 & 0 & 1.0 \\
\hline $11 \mathrm{H}-4,93$ & 92.53 & 21.8 & 130 & 0 & 58 & 0 & 106 & 0 & 1.2 & 0 & 0 & 1.0 \\
\hline $11 \mathrm{H}-4,98$ & 92.58 & 0.7 & 462 & 0 & 0 & 0 & 67 & 0 & 6.9 & 0 & 0 & - \\
\hline $11 \mathrm{H}-4,100$ & 92.60 & 2.4 & 92 & 0 & 0 & 0 & 58 & 0 & 1.6 & 0 & 0 & - \\
\hline $11 \mathrm{H}-4,109$ & 92.69 & 6.4 & 46 & 0 & 0 & 0 & 110 & 0 & 0.4 & 0 & 0 & - \\
\hline $11 \mathrm{H}-4,115$ & 92.75 & 6.4 & 24 & 0 & 0 & 0 & 130 & 0 & 0.2 & 0 & 0 & - \\
\hline $11 \mathrm{H}-4,122$ & 92.82 & 18.7 & 61 & 0 & 0 & 0 & 166 & 0 & 0.4 & 0 & 0 & - \\
\hline $11 \mathrm{H}-4,125$ & 92.85 & 31.3 & 49 & 0 & 0 & 0 & 125 & 0 & 0.4 & 0 & 0 & - \\
\hline $11 \mathrm{H}-4,132$ & 92.92 & 8.1 & 45 & 0 & 0 & 0 & 142 & 0 & 0.3 & 0 & 0 & - \\
\hline $11 \mathrm{H}-5,30$ & 93.40 & - & 119 & 0 & 0 & 56 & 96 & 0 & 1.2 & 0.6 & 0 & - \\
\hline $11 \mathrm{H}-5,49$ & 93.59 & - & 96 & 0 & 58 & 106 & 55 & 0 & 1.7 & 1.9 & 0 & 1.0 \\
\hline $11 \mathrm{H}-5,59$ & 93.69 & 0.6 & 70 & 0 & 38 & 102 & 46 & 0 & 1.5 & 2.2 & 0 & 1.0 \\
\hline $11 \mathrm{H}-5,66$ & 93.76 & - & 106 & 0 & 61 & 240 & 119 & 0 & 0.9 & 2.0 & 0 & 1.0 \\
\hline $11 \mathrm{H}-5,105$ & 94.15 & 0.2 & 125 & 22 & 0 & 204 & 98 & 0 & 1.3 & 2.1 & 0 & 0 \\
\hline $11 \mathrm{H}-6,88$ & 95.48 & 0.3 & 169 & 10 & 58 & 10 & 114 & 0 & 1.5 & 0.1 & 0 & 0.9 \\
\hline${ }^{a} 11 \mathrm{H}-6,129$ & 95.89 & - & 494 & 109 & 1178 & 354 & 372 & 0 & 1.3 & 1.0 & 0 & 0.9 \\
\hline $11 \mathrm{H}-6,135$ & 95.95 & 0.2 & 100 & 13 & 22 & 59 & 64 & 0 & 1.6 & 0.9 & 0 & 0.6 \\
\hline${ }^{a} 11 \mathrm{H}-6,146$ & 96.06 & - & 859 & 0 & 387 & 676 & 466 & 0 & 1.8 & 1.5 & 0 & 1.0 \\
\hline${ }^{\mathrm{a}} 11 \mathrm{H}-7,14$ & 96.24 & - & 709 & - & - & 321 & 314 & 0 & 2.3 & 1.0 & 0 & - \\
\hline $12 \mathrm{H}-1,109$ & 97.69 & 0 & 92 & 0 & 0 & 10 & 180 & 0 & 0.5 & 0.1 & 0 & - \\
\hline $12 \mathrm{H}-2,105$ & 99.15 & 0 & 142 & 10 & 46 & 10 & 117 & 0 & 1.2 & 0.1 & 0 & 0.8 \\
\hline $12 \mathrm{H}-3,105$ & 100.65 & 0.1 & 128 & 86 & 55 & 10 & 166 & 0 & 0.8 & 0.1 & 0 & 0.4 \\
\hline $12 \mathrm{H}-4,18$ & 101.28 & 0.3 & 188 & 40 & 52 & 10 & 142 & 29 & 1.3 & 0.1 & 0.2 & 0.6 \\
\hline $12 \mathrm{H}-4,105$ & 102.15 & 0.1 & 18 & 45 & 50 & 0 & 121 & 0 & 0.1 & 0 & 0 & 0.5 \\
\hline a $12 \mathrm{H}-5,60$ & 103.20 & - & 1262 & 109 & 1067 & 0 & 713 & 0 & 1.8 & 0 & 0 & 0.9 \\
\hline $12 \mathrm{H}-5,105$ & 103.65 & 0.2 & 139 & 22 & 79 & 0 & 156 & 0 & 0.9 & 0 & 0 & 0.8 \\
\hline $12 \mathrm{H}-6,96$ & 105.06 & - & 137 & 85 & 137 & 10 & 154 & 0 & 0.9 & 0.1 & 0 & 0.6 \\
\hline${ }^{a} 13 \mathrm{H}-1,78$ & 106.88 & - & 1204 & 224 & 713 & 0 & 331 & 0 & 3.6 & 0 & 0 & 0.8 \\
\hline $13 \mathrm{H}-1,105$ & 107.15 & 48.3 & 92 & 12 & 10 & 10 & 85 & 0 & 1.1 & 0.1 & 0 & 0.5 \\
\hline $13 \mathrm{H}-2,105$ & 108.65 & 62.4 & 130 & 18 & 10 & 18 & 72 & 0 & 1.8 & 0.3 & 0 & 0.4 \\
\hline $13 \mathrm{H}-3,105$ & 110.15 & 68.1 & 44 & 10 & 0 & 0 & 72 & 0 & 0.6 & 0 & 0 & 0 \\
\hline $13 \mathrm{H}-3,148$ & 110.58 & 30.4 & 156 & 10 & 0 & 10 & 79 & 0 & 2.0 & 0.1 & 0 & 0 \\
\hline $13 \mathrm{H}-4,105$ & 111.65 & 58.6 & 128 & 12 & 0 & 0 & 67 & 0 & 1.9 & 0 & 0 & 0 \\
\hline $13 \mathrm{H}-5,105$ & 113.15 & 60.4 & 119 & 10 & 0 & 0 & 86 & 0 & 1.4 & 0 & 0 & 0 \\
\hline $13 \mathrm{H}-6,105$ & 114.65 & 43.2 & 119 & 14 & 0 & 0 & 67 & 0 & 1.8 & 0 & 0 & 0 \\
\hline $14 \mathrm{H}-1,105$ & 116.40 & 0.4 & 234 & 45 & 35 & 10 & 106 & 0 & 2.2 & 0.1 & 0 & 0.4 \\
\hline $14 \mathrm{H}-2,105$ & 117.80 & 46.5 & 100 & 0 & 0 & 0 & 71 & 0 & 1.4 & 0 & 0 & - \\
\hline${ }^{\mathrm{a}} 14 \mathrm{H}-3,50$ & 118.60 & - & 771 & 476 & 155 & 0 & 395 & 0 & 2.0 & 0 & 0 & 0.2 \\
\hline $14 \mathrm{H}-5,105$ & 121.68 & 0.3 & 172 & 58 & 92 & 10 & 94 & 0 & 1.8 & 0.1 & 0 & 0.6 \\
\hline $14 \mathrm{H}-6,105$ & 122.97 & 0.2 & 151 & 45 & 64 & 10 & 98 & 0 & 1.5 & 0.1 & 0 & 0.6 \\
\hline $14 \mathrm{H}-7,105$ & 124.26 & 11.3 & 164 & 10 & 62 & 10 & 94 & 0 & 1.7 & 0.1 & 0 & 0.9 \\
\hline $14 \mathrm{H}-8,105$ & 125.10 & - & 135 & 10 & 0 & 42 & 69 & 0 & 2.0 & 0.6 & 0 & 0 \\
\hline${ }^{a} 15 \mathrm{H}-1,70$ & 125.80 & - & 1398 & 342 & 346 & 0 & 138 & 0 & 10.1 & 0 & 0 & 0.5 \\
\hline $15 \mathrm{H}-1,105$ & 126.15 & 3.6 & 207 & 10 & 46 & 10 & 71 & 0 & 2.9 & 0.1 & 0 & 0.8 \\
\hline $15 \mathrm{H}-2,105$ & 127.65 & 12.7 & 154 & 24 & 30 & 10 & 67 & 0 & 2.3 & 0.1 & 0 & 0.6 \\
\hline $15 \mathrm{H}-3,105$ & 129.15 & 0.1 & 123 & 10 & 44 & 10 & 64 & 0 & 1.9 & 0.2 & 0 & 0.8 \\
\hline $15 \mathrm{H}-4,105$ & 130.65 & 12.8 & 174 & 45 & 38 & 10 & 88 & 0 & 2.0 & 0.1 & 0 & 0.5 \\
\hline $15 \mathrm{H}-5,105$ & 132.15 & 14 & 210 & 42 & 37 & 10 & 52 & 0 & 4.0 & 0.2 & 0 & 0.5 \\
\hline $16 \mathrm{H}-1,102$ & 135.62 & 32.2 & 256 & 25 & 0 & 0 & 94 & 0 & 2.7 & 0 & 0 & 0 \\
\hline $16 \mathrm{H}-2,103$ & 137.13 & 18.8 & 269 & 55 & 23 & 0 & 69 & 0 & 3.9 & 0 & 0 & 0.3 \\
\hline $16 \mathrm{H}-3,103$ & 138.63 & 1.5 & 269 & 83 & 20 & 0 & 69 & 0 & 3.9 & 0 & 0 & 0.2 \\
\hline $18 \mathrm{X}-1,7$ & 153.67 & 14.8 & 169 & 71 & 17 & 0 & 106 & 0 & 1.6 & 0 & 0 & 0.2 \\
\hline $18 \times-2,105$ & 156.15 & 24.7 & 182 & 100 & 23 & 0 & 67 & 0 & 2.7 & 0 & 0 & 0.2 \\
\hline $19 X-1,9$ & 163.19 & 0.4 & 266 & 121 & 45 & 0 & 94 & 0 & 2.8 & 0 & 0 & 0.3 \\
\hline $19 X-2,105$ & 165.65 & - & 202 & 0 & 0 & 0 & 154 & 0 & 1.3 & 0 & 0 & - \\
\hline $20 \mathrm{X}-1,24$ & 172.84 & 0.5 & 365 & 40 & 0 & 10 & 110 & 90 & 3.3 & 0.1 & 0.8 & 0 \\
\hline$a_{21 X}-2,110$ & 184.70 & - & 1726 & - & - & 417 & 507 & 5508 & 3.4 & 0.8 & 10.9 & - \\
\hline $21 X-3,16$ & 185.26 & 0.4 & 566 & 0 & 0 & 66 & 59 & 480 & 9.6 & 1.1 & 8.1 & - \\
\hline $22 \mathrm{X}-1,15$ & 191.75 & 1.0 & 388 & 50 & 0 & 14 & 100 & 282 & 3.9 & 0.1 & 2.8 & 0 \\
\hline${ }^{a} 22 X-2,131$ & 194.41 & - & 1196 & - & - & 159 & 407 & 756 & 2.9 & 0.4 & 1.9 & - \\
\hline $23 \mathrm{X}-2,50$ & 203.10 & 0.6 & 279 & 69 & 0 & 72 & 85 & 121 & 3.3 & 0.8 & 1.4 & 0 \\
\hline a $23 \mathrm{X}-3,46$ & 204.56 & - & 1102 & - & - & 363 & 552 & 0 & 2.0 & 0.7 & 0 & - \\
\hline $24 X-2,50$ & 212.60 & 0.2 & 369 & 37 & 0 & 46 & 130 & 471 & 2.8 & 0.4 & 3.6 & 0 \\
\hline $24 \mathrm{X}-2,134$ & 213.44 & 0.3 & 320 & 53 & 0 & 92 & 100 & 428 & 3.2 & 0.9 & 4.3 & 0 \\
\hline $25 \mathrm{X}-2,50$ & 222.10 & 0.3 & 262 & 28 & 0 & 10 & 83 & 177 & 3.2 & 0.1 & 2.1 & 0 \\
\hline $25 X-5,27$ & 226.37 & 0.3 & 342 & 40 & 0 & 256 & 121 & 780 & 2.8 & 2.1 & 6.4 & 0 \\
\hline${ }^{\mathrm{a}} 26 \mathrm{X}-1,80$ & 230.40 & - & 1027 & 838 & 0 & 872 & 272 & 2417 & 3.8 & 3.2 & 8.9 & 0 \\
\hline $26 \mathrm{X}-3,39$ & 232.99 & 0.3 & 250 & 81 & 0 & 10 & 88 & 250 & 2.8 & 0.1 & 2.8 & 0 \\
\hline $27 X-1,68$ & 239.78 & 0.3 & 237 & 67 & 0 & 10 & 71 & 139 & 3.3 & 0.1 & 2.0 & 0 \\
\hline $28 \mathrm{X}-1,140$ & 250.00 & 2.3 & 317 & 72 & 22 & 10 & 94 & 256 & 3.4 & 0.1 & 2.7 & 0.2 \\
\hline
\end{tabular}


Table 2 (continued).

\begin{tabular}{|c|c|c|c|c|c|c|c|c|c|c|c|c|}
\hline \multirow{2}{*}{$\begin{array}{l}\text { Core, section, } \\
\text { interval }(\mathrm{cm})\end{array}$} & \multirow{2}{*}{$\begin{array}{l}\text { Depth } \\
\text { (mbsf) }\end{array}$} & \multirow{2}{*}{$\begin{array}{c}\mathrm{CaCO}_{3} \\
(\%)\end{array}$} & \multicolumn{6}{|c|}{ Relative X-ray diffraction intensities } & \multirow[b]{2}{*}{ Qua/Hal } & \multirow[b]{2}{*}{$\mathrm{Zeo} / \mathrm{Hal}$} & \multirow[b]{2}{*}{$\mathrm{CT} / \mathrm{Hal}$} & \multirow{2}{*}{$\frac{K}{K+I}$} \\
\hline & & & Quartz & Illite & Kaolinite & Zeolites & Halite & Opal-CT & & & & \\
\hline${ }^{2} 28 X-4,120$ & 254.30 & - & 699 & - & 0 & 377 & 209 & 4943 & 3.3 & 1.8 & 23.7 & - \\
\hline${ }^{a} 29 X-2,58$ & 260.18 & - & 263 & 432 & 0 & 231 & 350 & 4120 & 0.8 & 0.7 & 11.8 & 0 \\
\hline $29 \times-4,9$ & 262.69 & 0.8 & 276 & 19 & 0 & 17 & 83 & 497 & 3.3 & 0.2 & 6.0 & 0 \\
\hline $30 \mathrm{X}-1,108$ & 268.68 & 0.4 & 331 & 34 & 0 & 10 & 151 & 416 & 2.2 & 0.1 & 2.8 & 0 \\
\hline${ }^{\mathrm{a}} 30 \mathrm{X}-2,112$ & 270.22 & - & 1503 & 503 & 0 & 147 & 361 & 5378 & 4.2 & 0.4 & 14.9 & 0 \\
\hline $31 X-4,10$ & 281.70 & 1.1 & 210 & 137 & 0 & 10 & 59 & 125 & 3.6 & 0.2 & 2.1 & 0 \\
\hline $32 \mathrm{X}-1,58$ & 287.18 & 0.3 & 497 & 37 & 0 & 34 & 41 & 870 & 12.1 & 0.8 & 21.2 & 0 \\
\hline
\end{tabular}

Note: Because chlorite is of minor importance, the $7.1 \AA \AA$ intensity values can be used as estimates for the kaolinite content (Stein, $1985 \mathrm{~b}$; Stein, unpubl. data).

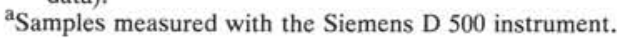

tions in Ruddiman, Sarnthein, et al., 1988). The rate of bioturbation remains moderate to high.

Interval I has extremely low carbonate contents (around $1 \%$; Fig. 2, Table 2). The bulk mineralogy is dominated by zeolites (heulandite and/or clinoptilolite), quartz, illite/mica, and opal-CT (Fig. 2, Table 2).

\section{Interval II}

Sections $108-661 \mathrm{~A}-18 \mathrm{X}-\mathrm{CC}$ (163.1 mbsf) to $108-661 \mathrm{~A}-13 \mathrm{H}-1$ (106.1 mbsf)

Interval II is characterized by cyclic sedimentation caused by changes in the carbonate content, with a general increase in carbonate from the lower to the upper part of the interval. In the lower part (i.e., Core 108-661A-18X to Section 108661A-14H-3), light olive brown nannofossil clay alternates with greenish gray clay; carbonate values vary between $0 \%$ and about $30 \%$ (Fig. 2, Table 2). In the upper part (i.e., Section 108-661A-14H-2 to Core 108-661A-13H), light greenish gray nannofossil ooze alternates with greenish gray nannofossil clay or clay; carbonate values vary between $0 \%$ and almost $70 \%$ (Fig. 2, Table 2). The thicknesses of the cycles show large-scale variations, ranging from $15 \mathrm{~cm}$ to $>100 \mathrm{~cm}$. In a few sections (i.e., in Sections 108-661A-13H-6 and 108-661A-14H-7), very small-scale cycles of $<10$-cm thickness are recorded.

The degree of bioturbation is very similar to that in Interval I (i.e., moderate to strong).

In Interval II, pyrite is of minor importance, with the exception of Core 108-661A-14H where dark pyrite nodules and lamination occur (Ruddiman, Sarnthein, et al., 1988). According to bulk mineralogy analyses, opal-CT is absent and the amounts of zeolites are generally distinctly less in this interval than in the underlying Interval I (Fig. 2, Table $2)$. Zeolites seem to be very rare or absent in the lower Cores $108-661 \mathrm{~A}-18 \mathrm{X}$ to $-16 \mathrm{H}$ and more abundant in Cores 108 $661 \mathrm{~A}-15 \mathrm{H}$ to $-13 \mathrm{H}$. Even in the latter cores, zeolites are not present throughout the cores, but they do occur at certain levels (Fig. 2, Table 2). According to these new and more detailed data, the zeolite content in the core descriptions, which was based on a few shipboard smear slides (Ruddiman, Sarnthein, et al., 1988), is partly overestimated in Interval II.

The XRD analyses of bulk sediments indicate the dominance of calcite and quartz and some amounts of clay minerals such as illite/mica and zeolites (Fig. 2, Table 2). Kaolinite is of minor importance in the lower and upper parts of the interval. In the middle part, however, some higher amounts of kaolinite were recorded (Fig. 2, Table 2).

\section{Interval III}

Sections 108-661A-12H-CC (106.1 mbsf) to $108-661 \mathrm{~A}-12 \mathrm{H}-1$, $110 \mathrm{~cm}$ (97.7 mbsf)

Interval III is mainly composed of homogeneous greenish gray clay. Only in Sections 108-661A-12H-2 and -3 are weak laminations on the scale of $1 \mathrm{~mm}$ to $1 \mathrm{~cm}$ present. Pyrite nodules are scattered in the lower part of this interval (i.e., Sections 108-661A-12H-4 to 108-661A-12H-6). In comparison with other intervals, bioturbation is of minor importance.

Carbonate contents are extremely low throughout the entire interval (i.e., <1\%; Fig. 2, Table 2). The amounts of zeolites are as low as in Interval II (Fig. 2, Table 2). Zeolites seem to be absent in Sections 108-661A-12H-4 and 108$661 \mathrm{~A}-12 \mathrm{H}-5$. The bulk mineralogy is dominated by quartz, illite/mica, and kaolinite (Fig. 2, Table 2).

\section{Interval IV}

Sections $108-661 \mathrm{~A}-12 \mathrm{H}-1,110 \mathrm{~cm}$ (97.7 mbsf) to 108-661A-11H-3, $30 \mathrm{~cm}$ (90.8 mbsf)

Interval IV is very different from the other rather homogeneous underlying intervals. It is characterized by several abrupt changes in color and mineralogy. Most of the interval is composed of brownish yellow, moderately bioturbated clay in which two distinct horizons of variegated sediments (H1 and $\mathrm{H}_{2}$ ) and numerous dark nodules and layers are interbedded (Figs. 5, 6, 7, and 8; also see the whole-core photographs in Ruddiman, Sarnthein, et al., 1988). In horizons H1 and H2, the amount of silty material is distinctly higher than in the interbedded, more clayey sediments (Table 1).

The lower brownish clay (i.e., Section 108-661A-12H-1, $110 \mathrm{~cm}$, to $108-661 \mathrm{~A}-11 \mathrm{H}-5,0 \mathrm{~cm})$ shows high concentrations of black sediments, especially in Sections 108-661A-11H-6, 95 $\mathrm{cm}$, to $108-661 \mathrm{~A}-11 \mathrm{H}-\mathrm{CC}$. The black color is caused by manganese oxides (Wosnitza, pers. comm., 1988). The carbonate content is very similar to the underlying interval $(<1 \%$; Fig. 2); however, an important difference is recorded in the zeolite contents, which distinctly increased (Fig. 2, Table 2). No other distinct change in the bulk mineralogy appears; that is, quartz, illite/mica, and kaolinite remain the major associated components (Figs. 2 and 7).

Horizon $\mathrm{H} 1$ occurs inside the lower brownish clay in Section 108-661A-11H-5, 65-35 cm (Figs. 5 and 7). The bulk mineralogy of horizon $\mathrm{H} 1$ is very similar to that of the lower brownish clay; that is, quartz, zeolites, illite/mica, and kaolinite are the major components (Figs. 2 and 7).

Horizon $\mathrm{H} 1$ can be subdivided into three layers interbedded by brownish clay. The lower layer $(65-51 \mathrm{~cm})$, com- 


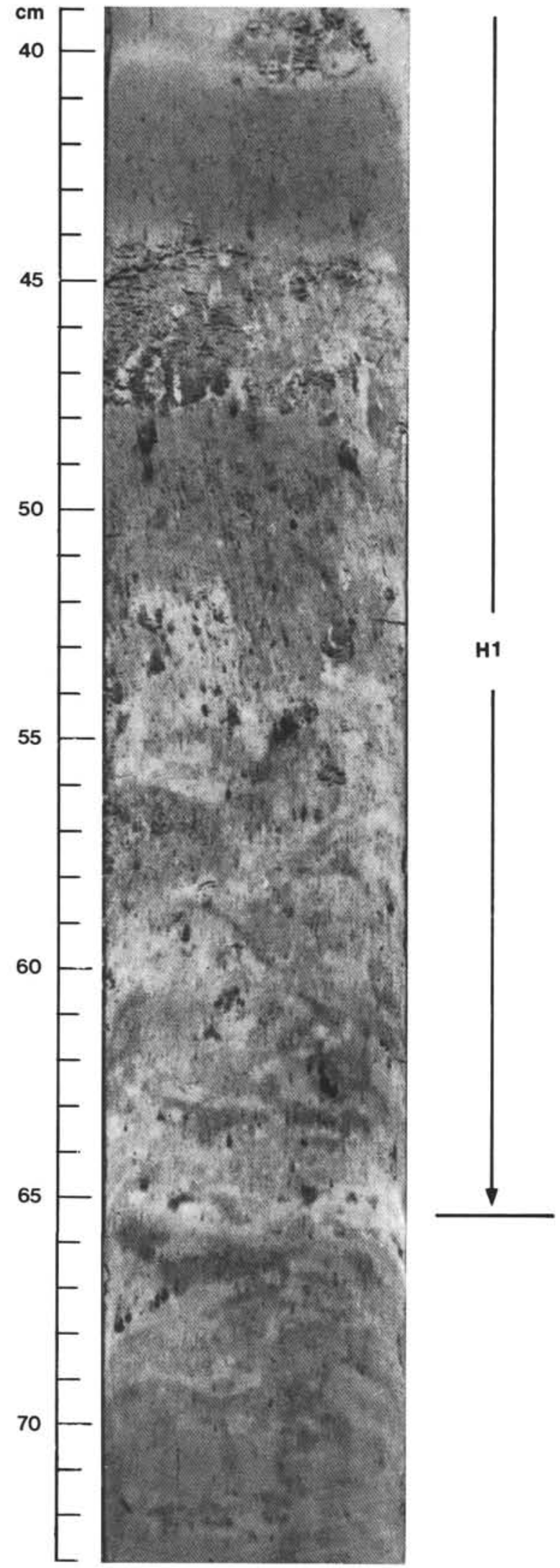

Figure 5. Section 108-661A-11H-5, 39-73 cm, photograph of horizon $\mathrm{H} 1$. Scale in centimeters. The uppermost part of the horizon is missing on this photograph (see Fig. 7).

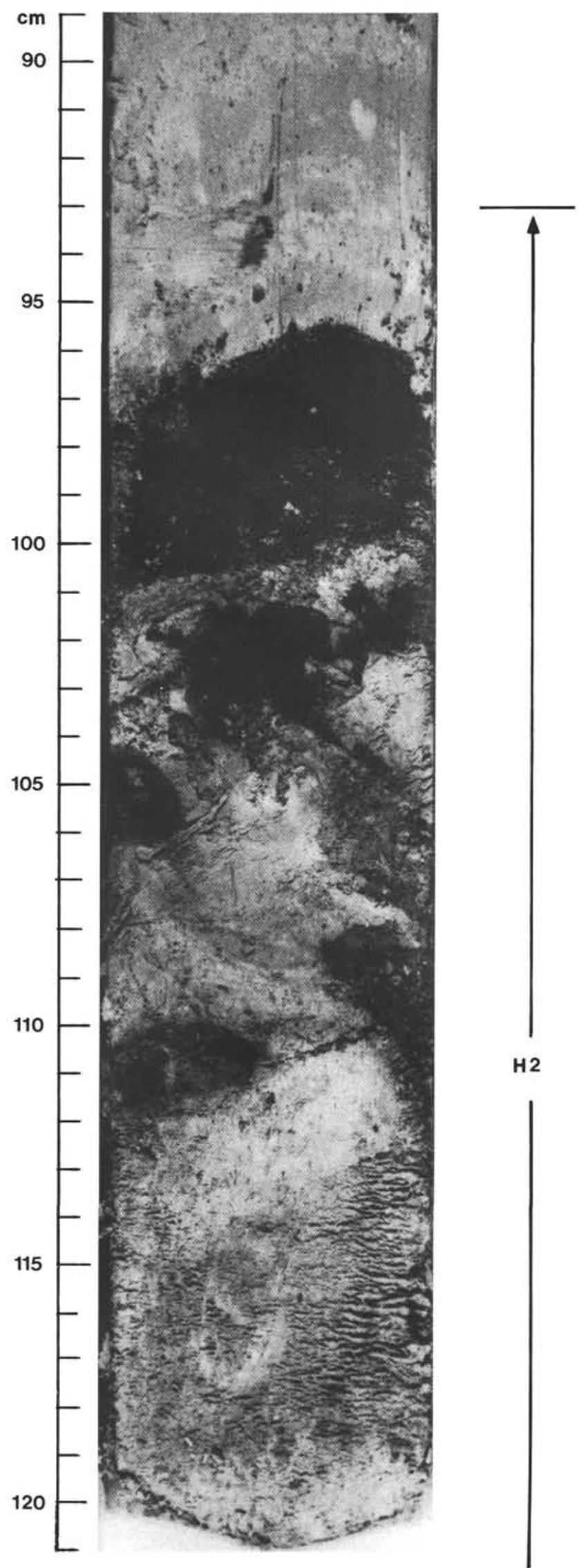

Figure 6. Section 108-661A-11H-4, 89-121 cm, photograph of the upper part of horizon $\mathrm{H} 2$. Scale in centimeters. For the lower part, see Figures 8 and 9. 


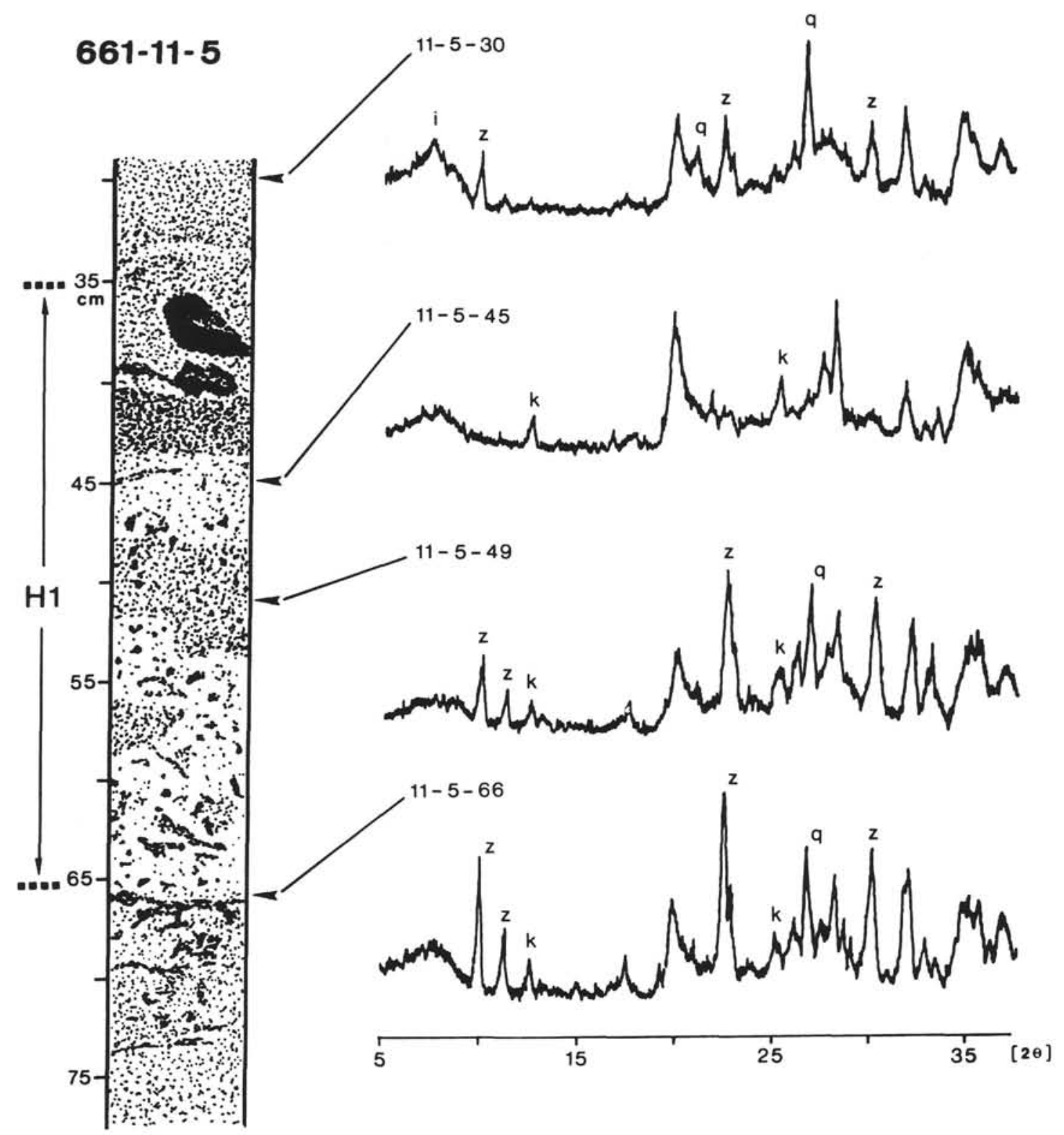

Figure 7. Results of XRD analyses from sediment samples of horizon H1, Section 108-661A-11H-5: Samples $108-661 \mathrm{~A}-11 \mathrm{H}-5,30 \mathrm{~cm}, 45 \mathrm{~cm}, 49 \mathrm{~cm}$, and $66 \mathrm{~cm}$. Scale on the left margin in centimeters. $\mathrm{q}=$ quartz, $\mathrm{c}=$ calcite, $\mathrm{i}$ $=$ illite, $\mathrm{z}=$ zeolites, $\mathrm{a}=$ apatite, $\mathrm{k}=$ kaolinite, $\mathrm{d}=$ dolomite, and $\mathrm{b}=$ baryte.

posed of mottled light gray to dark gray sediments, shows gradational contacts to the underlying as well as to the overlying brownish clay (Fig. 5). The middle layer (47-44 $\mathrm{cm}$ ) displays sharp irregular (erosional?) contacts and consists of mottled dark greenish gray sediments (Fig. 5). The third layer $(41-35 \mathrm{~cm})$ shows a sharp basal contact and two isolated pebbles composed of sediments similar to the underlying middle layer.

Horizon H2 (Section 108-661A-11H-4, 143-92 cm) occurs between the lower and upper brownish clay and can be clearly distinguished from the underlying part of Interval IV by higher carbonate proportions and the absence of zeolites and kaolinite (Fig. 2, Table 2). The horizon itself is composed of two different sediment facies. The lower part $(143-121 \mathrm{~cm})$ and the top of the horizon $(96-92 \mathrm{~cm})$ are white-gray homogeneous sediments with relatively sharp contacts to the underlying and overlying brownish clay. Carbonate ranges from $8 \%$ to $>30 \%$ and consists mainly of dolomite (Figs. 2 and 8, Table 2). Apatite and baryte are also present (Fig. 8).

The second sediment facies (Section 108-661A-11H-4, $121-96 \mathrm{~cm}$ ) is characterized by yellow to orange sediments with dark brown and bluish black nodules (Fig. 6). Carbonate contents are lower (i.e., $<6 \%$; Fig. 2) than in surrounding sediments of light color. The sediments below the large nodule (about $6 \mathrm{~cm}$ in diameter) have high contents of quartz and apatite (Fig. 8).

The large, $6-\mathrm{cm}$-diameter nodule of horizon $\mathrm{H} 2$ occurs just on top of the yellowish sediment with imbricated and sharp contacts to the yellowish sediment and other black and bluish nodules and (?) burrows infill (Figs. 6 and 8). Determinations of major and minor elements of sediments from horizon $\mathrm{H} 2$ obtained by X-ray fluorescence (XRF) analyses 


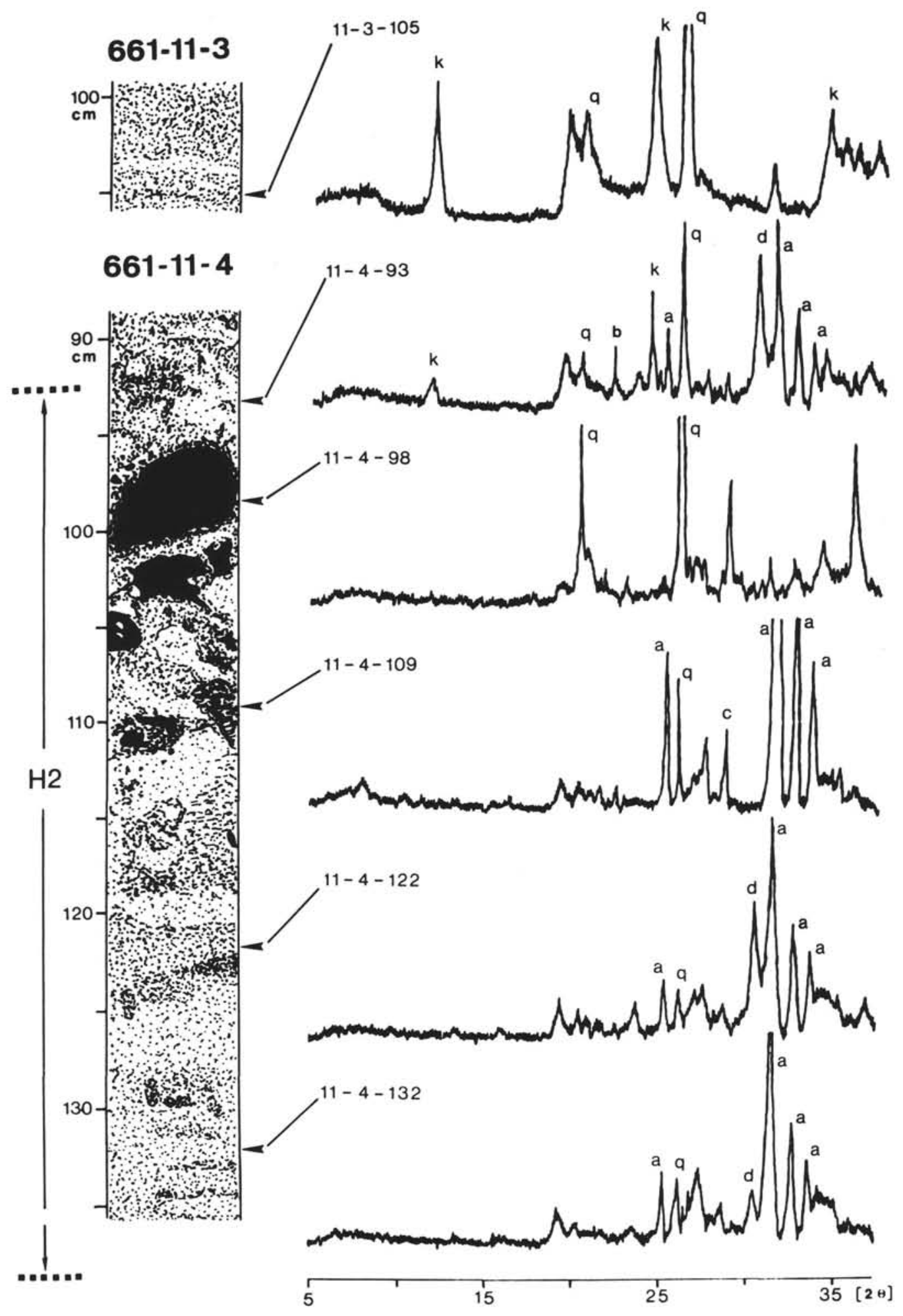

Figure 8. Results of XRD analyses from sediment samples of horizon H2; Sections 108-661A-11H-3 and 108-661A-11H-4: Sample 108-661A-11H-3, $105 \mathrm{~cm}$, and Samples 108-661A-11H-4, $93 \mathrm{~cm}, 98 \mathrm{~cm}, 109 \mathrm{~cm}, 122$ $\mathrm{cm}$, and $132 \mathrm{~cm}$. Scale on the left margin in centimeters. For further explanations, see Figure 7. 


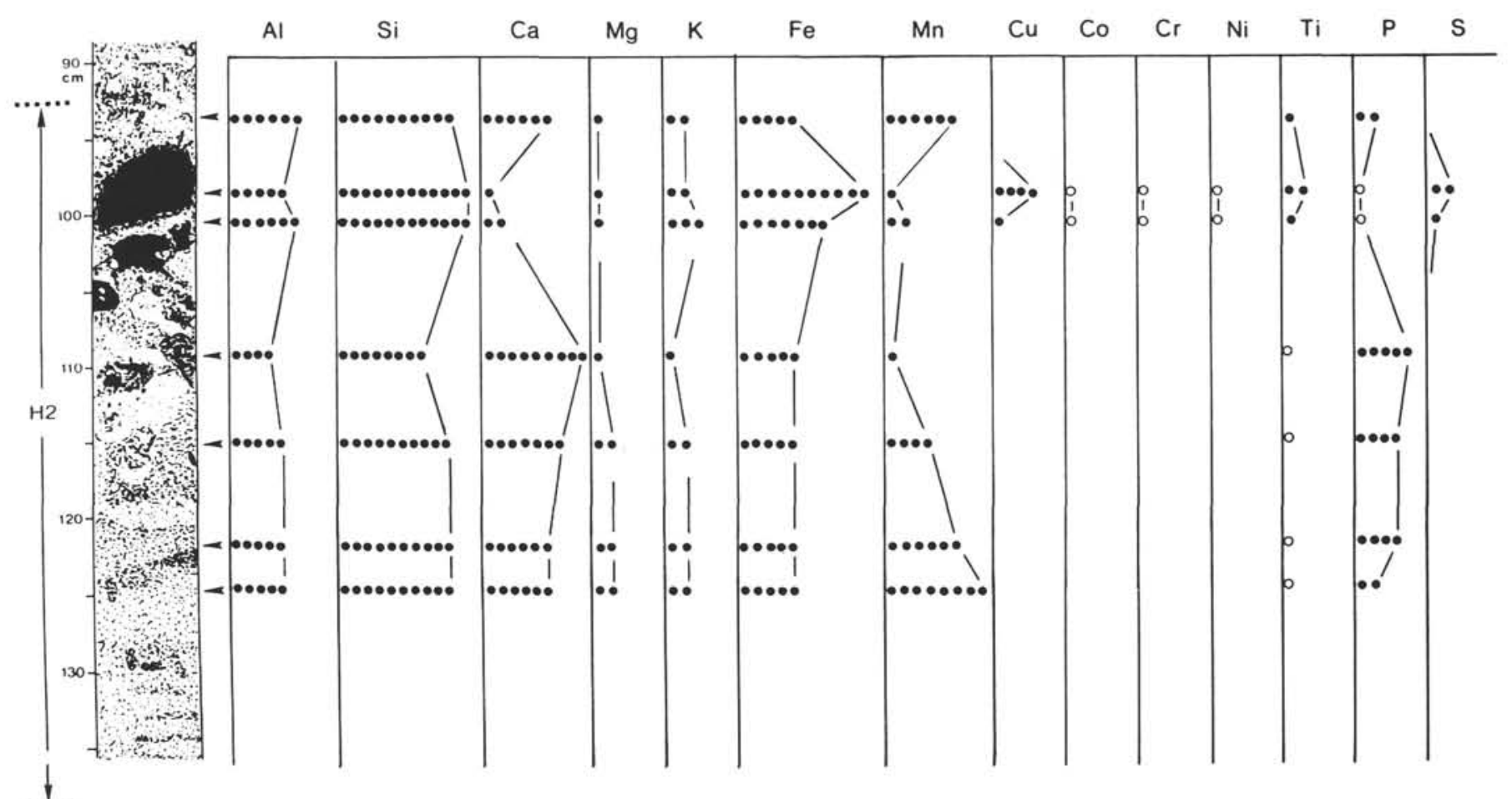

Figure 9. Minor and major elements obtained by XRF from sediment samples from horizon H2, Section 108-661A-11H-4. Scale on the left margin in centimeters. Data are qualitative estimates based on noncalibrated intensity values (Ruddiman, Sarnthein, et al., 1988). Open dots indicate intensity values slightly higher than the noise level.

(Fig. 9; Ruddiman, Sarnthein, et al., 1988) indicate that the nodule itself is distinctly enriched in iron, copper, cobalt, and nickel. Manganese values are low inside the nodule but are enriched in the underlying and overlying sediments (Fig: 9).

The upper brownish clay (Sections $108-661 \mathrm{~A}-11 \mathrm{H}-4$ to 108-661A-11H-3) has similar general characteristics to the lower brownish clay: same color, moderate bioturbation, very low carbonate content, and scattered black material. The main difference between both clays is the absence of zeolites and the dominance of kaolinite in the clay mineral composition in the upper clay (Figs. 2, 7, and 8; Table 2). Furthermore, two black nodules occur in Section 108-661A-11H-3 at about 85 and $95 \mathrm{~cm}$ that look very similar to the nodules in horizon $\mathrm{H} 2$. However, the two nodules are isolated in the surrounding brownish clay. Between them, we observed two rather sharp contacts in the brownish clay. These features are reminiscent of those described at the top of horizon H1 (Fig. 7).

\section{DISCUSSION AND INTERPRETATION OF THE RESULTS}

Based on the detailed sedimentological and geochemical investigation above, we were able to determine a reconstruction of the evolution of the depositional environment and sediment processes.

The main characteristics of the Campanian sediments (Fig. 2, Interval I; stratigraphic age based on radiolarians; J. Thurow, pers. comm., 1988) are a major occurrence of zeolites, opal-CT, and pyrite; an intense bioturbation; and an extremely low carbonate content. Because zeolites have been recorded over a long time interval of several million years and because long-lasting major volcanic episodes are not known in this area during this time interval, it is very likely that the zeolites originated from biogenic silica, that is, from opal-A (cf. Fenner, 1981; Stein, 1985b; Bohrmann and Stein, 1989a). Scanning electron microscope (SEM) photographs of radiolarian skeletons showing the original opal-A replaced by opal-CT (Bohrmann, pers. comm., 1988), the high opal-CT content (Fig. 2), and the pyritized radiolarian tests (J. Thurow, pers. comm., 1988) support the biogenic origin. All three parameters (i.e., biogenic opal, pyrite, and intense bioturbation) are characteristic of a well-oxygenated, high-productivity environment.

The absence of carbonate at Site 661 indicates a position below the calcite compensation depth $(\mathrm{CCD})$, resulting in strong carbonate dissolution and, thus, in a reduction of sedimentation rates. Furthermore, reduced sedimentation rates and well-oxygenated deep water can also explain the much too low amounts of organic matter preserved in the sediments of these high-productivity areas (about $0.2 \%$; Stein et al., this vol.). Therefore, most of the organic matter produced has been oxidized before it could be buried into the sediments. Indications for a relatively high productivity and a shallow CCD during Late Cretaceous times are also supported by data from other North Atlantic sites (e.g., Kennett, 1982; Ehrmann and Thiede, 1985).

The dominance of very fine-grained siliciclastic clays and claystones and the absence of any erosional features may indicate that the sediments were deposited in a low-energy environment. Transport mechanisms of nonauthigenic siliciclastic material (i.e., quartz and illite/mica) may have been winds and/or bottom-water currents. According to grain-size data, the vigor of each must have been distinctly lower than those recorded for Quaternary times (Mienert, 1986; Stein, 1985b).

If eolian input was important, the source area of the siliciclastic sediments deposited at Site 661 should have been 
from the deserts and semideserts in South Africa, because Site 661 was located south of the equator during Late Cretaceous times (Sclater et al., 1977), thereby preventing any dust supply from the north by northerly trade winds (cf. Stein, 1985b). Thus, southerly trade winds were the main wind system carrying dust from the continent to the site position. Other than the low wind speeds that dominated during Late Cretaceous times (cf. Lever and McCave, 1983), the long-distance transport of dust over several thousands of kilometers could explain the very fine-grained siliciclastic material at Site 661 . Furthermore, the high amounts of illite and the minor importance of kaolinite may support our hypothesis of a southern (nontropical) source of this material (cf. Stein, 1985b).

During Maestrichtian times, the CCD progressively deepened, reaching its deepest position during the upper Maestrichtian, as indicated by the distinct increase of carbonate in Interval II. The sharp depression of the CCD during the middle/upper Maestrichtian is a phenomena generally observed in the North Atlantic, resulting in basin-wide chalk deposition overlying the carbonate-poor Upper Cretaceous clay deposits (Kennett, 1982). The general deepening of the CCD is probably superimposed by short-term, climate-controlled fluctuations of the CCD resulting in cyclic changes in carbonate dissolution, as suggested from visible color cycles $(15 \mathrm{~cm}$ to $>100 \mathrm{~cm}$ in thickness) and high-amplitude variations in carbonate content typical for this time interval. Changes in the flux rates of noncarbonate material as a cause for carbonate content variations (i.e., dilution) is less probable because of the generally low input rate of the noncarbonate fraction to the Sierra Leone Rise area. This means that the rate is too low to explain a decrease in carbonate content from more than $60 \%$ to almost 0\% (cf. Dean et al., 1981; Stein, 1985b).

The deepening of the CCD during Maestrichtian times is paralleled by a decrease in both pyrite and zeolites in Site 661 sediments. At the same time, opal-CT also disappeared (Fig. 2). This may imply a general decrease of oceanic productivity in the Site 661 area (see above).

Very fine grain sizes, high amounts of quartz, and an illite-over-kaolinite dominance were the main characteristics of the siliciclastic sediments at Site 661 during the early Maestrichtian. Thus, (1) low-energy processes have dominated the depositional environment, and (2) the source area of the siliciclastic material still may have been the (nontropical) South African continent. In the middle Maestrichtian, the first increase in the kaolinite supply occurred, indicating a (tropical) source area for the terrigenous matter characterized by intense chemical weathering processes (cf. Stein, 1985b).

The main difference between the Maestrichtian (Interval II) and the following younger Interval III is the distinct decrease in carbonate content from about $60 \%$ to about $0 \%$ (Fig. 2), probably indicating a shallowing of the CCD. Therefore, Site 661 lay below the CCD during this time interval. A second difference is the kaolinite-over-illite dominance, which may suggest that the sediment supply came primarily from (northern) tropical areas. During early Tertiary times, Site 661 could have crossed the equator (Sclater et al., 1977) and drifted into the belt of the northern trade winds (Fig. 10). These trade winds may have carried kaolinite-rich dust from tropical regions to the site position (cf. Stein, 1985b), which suggests an early Tertiary age for the change in the clay mineral composition at Site 661 .

The grain-size data (Fig. 3 and Table 1) and the lack of erosional features in the sediment cores indicate that lowenergy processes also remained dominant during Interval III.

Several drastic changes in depositional environment must have occurred during the next younger time interval. Because
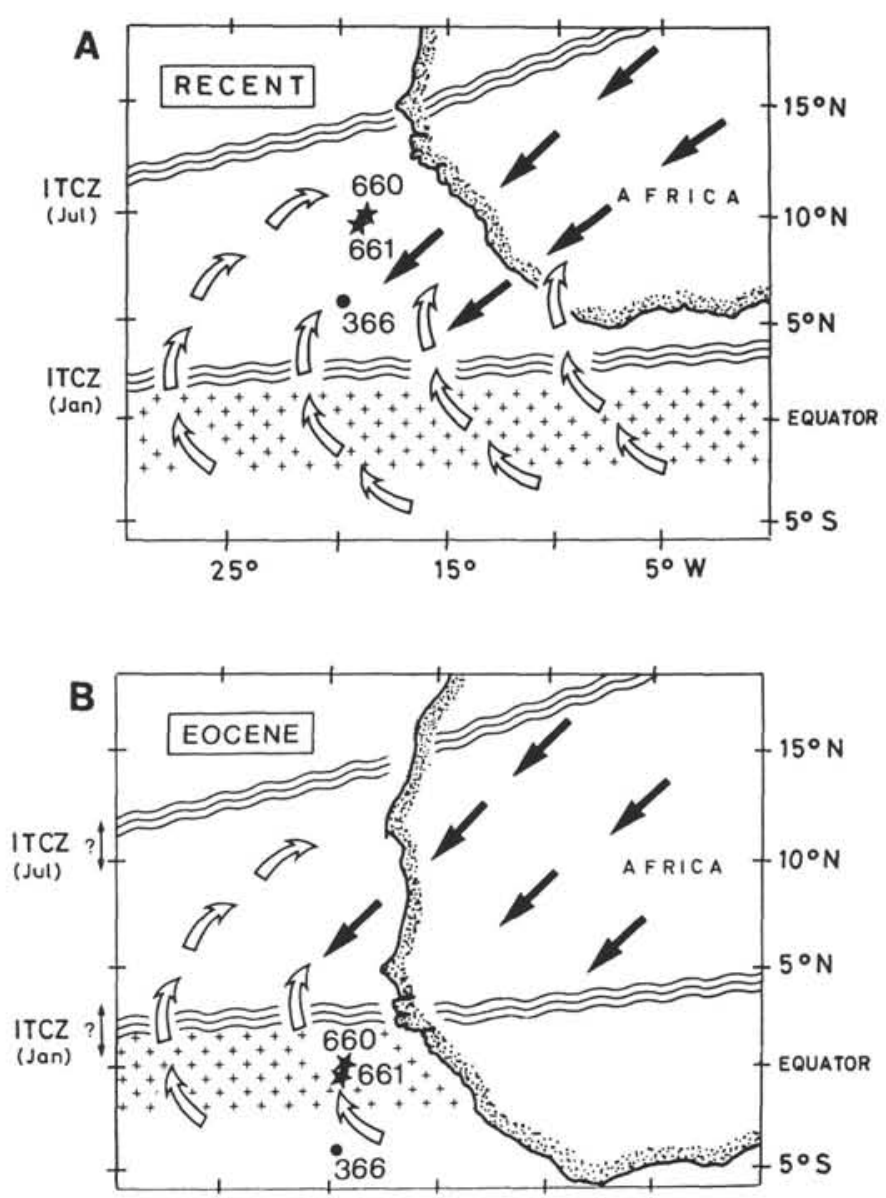

Figure 10. Wind regimes, dust supply, and oceanic upwelling in the eastern equatorial Atlantic. Black arrows indicate the dust supply by northeasterly trade winds during the northern winter when the InterTropical Convergence Zone (ITCZ) reaches its southernmost position. Open arrows indicate dust supply by the southeasterly trade winds during the northern summer when the ITCZ reaches its northernmost position (southeasterly trades continue north as southwesterly monsoonal winds after crossing the equator). Crosses mark equatorial upwelling area. A possible shift of the ITCZ would not affect the position of the center of the equatorial upwelling. A. Scheme of the modern situation with the present position of Sites 660 and 661 and Site 366. B. Scheme of the Eocene situation. Paleolatitude of the African continent and the sites according to Sclater et al. (1977). Figure modified after Stein (1985b).

of the lack of microfossils, an exact biostratigraphic dating of this part of the sequence was not possible. However, according to the overlying and underlying sequences, this interval was deposited between the uppermost Cretaceous and the lower upper Miocene (Ruddiman, Sarnthein, et al., 1988). Furthermore, the age-depth diagram at Site 661 (Ruddiman, Sarnthein, et al., 1988) shows that distinct changes in sedimentation rates and/or erosional events must have occurred in this interval.

The main characteristics of the lower part of this interval are the absence of carbonate and the high amounts of zeolites (Fig. 2), interpreted as a deposition (1) below the CCD and (2) underneath a high-surface-water productivity belt (i.e., the equatorial upwelling zone?; Fig. 10). This period possibly corresponds to the Eocene radiolarian ooze at nearby Site 660 (Fig. 1), also interpreted as a high-productivity indicator (Mienert et al., 1988). During Eocene times, siliceous sedi- 
ments (i.e., siliceous limestones, porcellanite, and chert nodules) and zeolite-rich sediments also occur at several other North Atlantic DSDP sites (e.g., Berger and von Rad, 1972; Riech and von Rad, 1979; von Rad et al., 1978; Bohrmann and Stein, 1989).

The simultaneity of deposition of the zeolitic clay at Site 661 and the radiolarian ooze at Site 660 may also be corroborated by the major occurrence of black manganese-rich laminae and layers in these intervals at both sites (Fig. 1; Ruddiman, Sarnthein et al., 1988). The manganese deposition (i.e., precipitation of manganese from the water column?) may indicate time periods of extremely reduced sedimentation rates. This process requires moderate bottom-current activities, which means that current velocities have prevented major depositions of fine-grained sediments. However, velocities were too low for sediment erosion.

A general characteristic of the following time period is the occurrence of major nodules/pebbles and sharp (erosional) contacts (Figs. 5-8, horizons $\mathrm{H} 1$ and $\mathrm{H} 2$ ), indicating phases of nondeposition and major bottom-current activities in the Kane Gap area.

Similar to the underlying sediments, the sediment of horizon $\mathrm{H} 1$ is characterized by the absence of carbonate, interpreted as deposition below the CCD. Zeolites still occur in high amounts. If zeolites are interpreted as indicators of high-productivity conditions, then the age of this interval should be Eocene (or older). During Eocene times, this site was inside the equatorial high-productivity area (Fig. 10), and the CCD in the (subtropical) Atlantic was as shallow as about $3500 \mathrm{~m}$ (Sclater et al., 1977; Berger, 1979).

On top of horizon H1, erosional surfaces and the two isolated pebbles composed of material similar to the underlying sediment (Fig. 6) may indicate erosional events and reworking processes. An exact timing of these phases of increased bottom-water activity is not possible because of the lack of microfossils.

The main characteristics of horizon $\mathrm{H} 2$ are the absence of zeolites, high amounts of carbonate (i.e., dolomite and calcite) and apatite, and the large nodule on top of the horizon (Table 2, Fig. 6). The absence of zeolites may imply a position for Site 661 outside the (equatorial) high-productivity area (see above). The presence of apatite and dolomite in horizon $\mathrm{H} 2$ suggests authigenic carbonate formation (cf. Bohrmann and Thiede, 1989).

The large nodule on top of horizon H2 (Fig. 6) is interpreted as an "altered manganese nodule." It is enriched in quartz, iron, copper, cobalt, and nickel, whereas manganese is removed in the nodule itself and enriched in the overlying and underlying sediments (Fig. 9). This alteration process (i.e., the mobilization of manganese) requires a change in redox potential to negative values.

If the growth process of this large nodule was similar to that of normal deep-sea manganese nodules (such as observed in the modern Pacific Ocean), then bottom currents must have been active over several millions of years, preventing sediment accumulation because growth rates of these manganese nodules were estimated to be as low as a few millimeters per million years (e.g., Guichard et al., 1978; Heath, 1981). Therefore, a further current-controlled hiatus probably exists on top of horizon $\mathrm{H} 2$. A recent example of a hiatus formed by bottom-current activity is recorded in the nearby central Kane Gap (Sarnthein et al., 1983; Mienert, 1986). Also, the hiatus there is marked by manganese nodules (Sarnthein et al., 1983).

The sediments above horizon $\mathrm{H} 2$ (i.e., the top of Unit 3) are characterized by the absence of carbonate and the dominance of quartz and kaolinite (Figs. 2 and 8). This is a sediment composition typical for a deposition below the CCD, outside any oceanic high-productivity area, and inside the influence of a terrigenous sediment supply from the tropical areas of northwest Africa (cf. Stein, 1985b). Two isolated nodules/pebbles and sharp (erosional?) contacts in Section 108-661A-11H-3 suggest further bottom-current activities during this time.

Widespread hiatuses (i.e., indicators of nondeposition and/or erosional events by bottom currents) were recorded at DSDP sites in the eastern North Atlantic Ocean during the Oligocene, between 35 and $20 \mathrm{Ma}$ (Moore et al., 1978). From the occurrence of contourites in sediments from the Bay of Biscay, Auffret and Pastouret (1979) also suggest the development of active bottom currents during Oligocene times. These data may imply an Oligocene to Miocene age for the erosion events recorded at Site 661 . Because of the lack of microfossils, an exact timing of these events is not possible at Site 661.

\section{CONCLUSIONS}

According to the sedimentological and geochemical data presented above, we have reached the conclusions that follow.

1. The sedimentary sequence of Unit 3 (Late Cretaceous and Tertiary) can be subdivided into four intervals:

Interval I (296.1-163.1 mbsf; Campanian age): characterized by a major occurrence of zeolites, opal-CT, pyrite, quartz, and illite, intense bioturbation, and the absence of carbonate and kaolinite;

Interval II (163.1-106.1 mbsf; Maestrichtian age): characterized by fluctuating carbonate contents, high amounts of quartz and illite, a strong decrease of zeolites, and the absence of pyrite;

Interval III (106.1-97.7 mbsf; between uppermost Cretaceous and early Tertiary): characterized by the absence of carbonate and zeolites, high amounts of quartz and illite, and the first occurrence of higher amounts of kaolinite; and

Interval IV (97.7-90.8 mbsf; between early Tertiary and late Miocene): characterized by changing contents of zeolites and carbonate, the occurrence of major nodules/pebbles and sharp (erosional) contacts, and major amounts of quartz and kaolinite.

2. Carbonate-free intervals indicate a depositional regime below the CCD (Campanian, ?Eocene).

3. Zeolite-rich and opal-CT-rich intervals are interpreted as periods of high oceanic productivity (Campanian, ?Eocene) when Site 661 was probably influenced by equatorial upwelling.

4. The major occurrence of kaolinite at Site 661 suggests a supply of terrigenous sediment fraction from tropical areas, starting during middle Maestrichtian and dominating during post-Maestrichtian times.

5. Manganese-rich black layers, major nodules/pebbles, and erosional surfaces indicate bottom-current activities and hiatus formation between early Tertiary and late Miocene times. Because of the lack of microfossils, an exact timing of these erosional events is not possible.

\section{ACKNOWLEDGMENTS}

We would like to thank D. Ortmann, R. Stax, and C. Weisner for technical assistance. We are indebted to J. Thurow for providing biostratigraphic data of the Campanian interval. We gratefully thank Drs. G. R. Heath and J. Mienert and one anonymous reviewer for their numerous constructive suggestions for the improvement of the manuscript. Support by the Deutsche Forschungsgemeinschaft (grant No. STE 412-1) is greatly appreciated.

\section{REFERENCES}

Auffret, G. A., and Pastouret, L., 1979. Upper Cretaceous to Quaternary sedimentary processes in the Bay of Biscay from textural, mineralogical, and coarse fraction studies. In Roberts, D. G., 
Montadert, L., et al., Init. Repts. DSDP, 48: Washington (U. S. Govt. Printing Office), 791-829.

Berger, W. H., 1979. Preservation of foraminifera. SEPM Short Course, 6:105-155.

Berger, W., and von Rad, U., 1972. Cretaceous and Cenozoic sediments from the Atlantic Ocean. In Hayes, D. E., Pimm, A. C., et al., Init. Repts. DSDP, 14: Washington (U. S. Govt. Printing Office), 787-954.

Bohrmann, G., and Stein, R., 1989. Biogenic silica at ODP Site 647 in the southern Labrador Sea: occurrence, diagenesis, and paleoceanographic implications. In Srivastava, S., Arthur, M. A., et al., Proc. ODP, Sci. Results, 105: College Station, TX (Ocean Drilling Program), 155-170.

Bohrmann, G., and Thiede, J., 1989. Diagenesis in Eocene claystones, ODP Site 647, Labrador Sea: formation of complex authigenic carbonates, smectites, and apatite. In Srivastava, S., Arthur, M. A., et al., Proc. ODP, Sci. Results, 105: College Station, TX (Ocean Drilling Program), 137-154.

Dean, W. E., Gardner, J. V., and Čepek, P., 1981. Tertiary carbonate-dissolution cycles on the Sierra Leone Rise, eastern equatorial Atlantic Ocean. Mar. Geol., 39:81-101.

Ehrmann, W., and Thiede, J., 1985. History of Mesozoic and Cenozoic sediment fluxes to the North Atlantic Ocean. Contrib. Sedimentol., 15:1-109.

Fenner, J., 1981. Diatoms in the Eocene and Oligocene sediments off northwest Africa: their stratigraphic and paleogeographic occurrences. [Ph.D. dissert.]. Univ. Kiel, Federal Republic of Germany.

Guichard, F., Reyss, J.-L., and Yokoyama, Y., 1978. Growth rate of manganese nodule measured with $10-\mathrm{Be}$ and $26-\mathrm{A} 1$. Nature, 272:155-156.

Heath, G. R., 1981. Ferromanganese nodules of the deep sea. Econ. Geol., 75:736-765.

Jacobi, R., and Hayes, D., 1982. Bathymetry, microphysiography, and reflectivity characteristics of the West African margin between Sierra Leone and Mauritania. In von Rad, U., Hinz, K., Sarnthein, M., and Seibold, E. (Eds.), Geology of the Northwest African Continental Margin: Berlin-Heidelberg-New York (Springer-Verlag), $182-212$.

Kennett, J., 1982. Marine Geology: New York (Prentice Hall).

Lever, A., and McCave, I. N., 1983. Eolian components in Cretaceous and Tertiary North Atlantic sediments. J. Sediment. Petrol., 53:811-832.

Mienert, J., 1986. Akustostratigraphie im üquatorialen Ost-atlantik: zur entwicklung der tiefenwasserzirkulation der letzten 3.5 millionen jahre. Meteor Forschungsergeb., Reihe C, 40:19-86.

Mienert, J., Stein, R., Schultheiss, P., and Shipboard Scientific Party, 1988. Relationship between grain density and biogenic opal in sediments from Sites 658 and 660. In Ruddiman, W., Sarnthein, M., et al., Proc. ODP, Init. Repts., 108, Sect. 2: College Station, TX (Ocean Drilling Program), 1047-1053.

Moore, T. C., Jr., van Andel, T. H., Sancetta, C., and Pisias, N., 1978. Cenozoic hiatuses in pelagic sediments. Micropaleontology, 24:113-138.

Riech, V., and von Rad, U., 1979. Eocene porcellanites and Early Cretaceous cherts from the western North Atlantic basin. In Tucholke, B. E., Vogt, P. R., et al., Init. Repts. DSDP, 43: Washington (U. S. Govt. Printing Office), 437-448.

Robbe, D., and Bertrand, R., 1987. Granulométrie des éléments fin par diffraction laser. Présentation et évaluation de la méthode. Bull. Liaison Lab., Ponts et Chaussees, 148:14-23.

Ruddiman, W., Sarnthein, M., et al., 1988. Proc. ODP, Init. Repts, 108: College Station, TX (Ocean Drilling Program).

Sarnthein, M., Kögler, F. C., and Werner, F., 1983. Report of the Meteor Cruise 65, equatorial east Atlantic (GEOTROPEX '83), June-August 1983, Kiel (Univ. Kiel).

Sarnthein, M., Thiede, J., Pflaumann, U., Erlenkeuser, H., Fütterer, D., Koopmann, B., Lange, H., and Seibold, E., 1982. Atmospheric and oceanic circulation patterns off northwest Africa during the past 25 million years. In von Rad, U., Hinz, K., Sarnthein, M., and Seibold, E. (Eds.), Geology of the Northwest African Continental Margin: Berlin-Heidelberg-New York (Springer-Verlag), 545-603.

Sclater, J. G., Hellinger, S., and Tapscott, C., 1977. The paleobathymetry of the Atlantic Ocean from the Jurassic to the Recent. J. Geol., 85:509-552.

Stein, R., 1985a. Rapid grain-size analyses of silt and clay fractions by SediGraph 5000D: comparison with Coulter Counter and Atterberg methods. J. Sediment. Petrol., 55:590-593.

1985b. The post-Eocene sediment record of DSDP Site 366: implications for African climate and plate tectonic drift. In Kennett, J. P. (Ed.), The Miocene Ocean: Paleoceanography and Biogeography. Mem. Geol. Soc. Am., 163:305-315.

von Rad, U., Riech, V., and Rösch, H., 1978. Silica diagenesis in continental margin sediments off northwest Africa. In Lancelot, Y., Seibold, E., et al., Init. Repts. DSDP, 41: Washington (U. S. Govt. Printing Office), 879-905.

Weber, O., Cremer, M., Faugères, J.-C., and Gonthier, E., in press. Sedigraph and Malvern grain-size analysis: a comparison of results obtained from clayey-silty siliciclastic marine sediments. Bull. Inst. Geol. Bassin Aquitaine.

Date of initial receipt: 22 January 1988

Date of acceptance: 11 November 1988 Ms 108B-135 